\title{
Effect of Organic Manures, Organic Supplements and Biofertilizers on Growth and Yield of Cowpea [Vigna unguiculata (L.) Walp]
}

\author{
Carol Lyngdoh*, Vijay Bahadur, A.A. David, V.M. Prasad and Tajungsola Jamir
}

Department of Horticulture, Sam Higginbottom University of Agriculture, Technology and Sciences, Allahabad - 211007, Uttar Pradesh, India

*Corresponding author

\section{A B S T R A C T}

Keywords

Cowpea, Organic manure, FYM,

Vermicompost,

Panchagavya,

Fish amino acid,

PSB and

Rhizobium.

Article Info

Accepted:

14 June 2017

Available Online:

10 August 2017
A field experiment was conducted at Horticulture farm, Department of Horticulture, SHUATS, Allahabad. The experiment consisted of two Bulky organic manures (FYM and Vermicompost), two liquid organic supplements (Fish Amino Acid (FAA) and Panchagavya) and Biofertilizers [Rhizobium and Phosphate Solubilizing Bacteria (PSB)]. The result revealed that treatment $\mathrm{T}_{14}$ (Vermicompost + Fish Amino Acid + Panchagavya + Biofertilizers) was found to be best in terms of plant height $(56.17 \mathrm{~cm})$, number of leaves $(57.07)$, number of branches (28.93), number of root nodules (21.73), length of pods $(36.84 \mathrm{~cm})$, width of pods $(0.69 \mathrm{~cm})$, days of germination (3.3), number of pods per plant (37.70), number of seeds per pod (14.10), pod weight (17.63), pod yield (254.03 $\mathrm{q} /$ ha) (4.7) followed by $\mathrm{T}_{13}$ (Vermicompost + Panchagavya + Biofertilizers) with plant height $(56.04 \mathrm{~cm})$, number of leaves (56.93), number of branches (27.67), number of root nodules (20.37), length of pods $(36.19 \mathrm{~cm})$, width of pods $(0.66$ $\mathrm{cm}$ ), days of germination (3.7), number of pods per plant (37.17), number of seeds per pod (13.93), pod weight (17.10), pod yield (240 q/ha).

\section{Introduction}

Cowpea is a warm season crop, annual and herbaceous legume cultivated throughout India like Kerala, Tamil Nadu, Andhra Pradesh, West Bengal, Punjab, Gujarat etc. It is also used as a green manuring crop.

The mature cowpea seeds contain around $25 \%$ protein, $63.6 \%$ carbohydrates, $1.9 \%$ fat, $6.3 \%$ fiber, $0.00074 \%$ Thiamine, $0.00042 \%$ Riboflavin and $0.0028 \%$ Niacin (Davis et al., 2000). Its grain is nutritious and is a cheap source of protein for both rural and urban consumers. Plant can tolerate drought and it also fixes atmospheric nitrogen. Land resources are degrading due to intensive cultivation and use of chemical fertilizers, pesticide and weedicide. This has caused environmental imbalance and it is causing problem to all living being on the Earth. The soil is becoming low and deficient in organic content (Baloch et al., 2014). Persistent nutrient depletion is posing a greater threat to the sustainable agriculture. Therefore, there is an urgent need to reduce the usage of chemical fertilizers and in turn increase the usage of organic manures and organic 
fertilizers which are needed to improve the yield and quality of the produce.

Farm yard manure supplies nitrogen, phosphorus, potassium and micronutrients like $\mathrm{Fe}, \mathrm{S}$, Mo and $\mathrm{Zn}$ etc. It improves physical and chemical properties and health of soil such as aggregation, aeration, permeability, water holding capacity, slow release of nutrients, increase in cation exchange capacity, stimulation of soil flora and fauna etc. On an average, it contains 0.50 , 0.17 and 0.55 per cent of $\mathrm{N}, \mathrm{P}$ and $\mathrm{K}$, respectively (Gaur, 1991). Vermicompost is an aerobically degraded organic matter produced with the help of worms. It contains 0.80 to $1.10 \% \mathrm{~N}, 0.40$ to $0.80 \% \mathrm{P}_{2} \mathrm{O}_{5}$ and 0.80 to $0.98 \% \mathrm{~K}_{2} \mathrm{O}, 10$ to $52 \mathrm{ppm} \mathrm{Cu}, 186.60 \mathrm{ppm}$ $\mathrm{Zn}, \quad 930.00 \mathrm{ppm} \mathrm{Fe}$ and plant growth promoting substances such as NAA, cytokinins, gibberellins, etc. (Giraddi 2001). It improves physico-chemical properties of the soil and enhances the microbial, crop growth and yield (Vansanthi and Kumaraswamy, 1999).

Use of panchagavya and fish amino acid improves the soil and plants health also providing protective measures against plant diseases. Panchagavya and fish amino acid enhances the biological efficiency of the crop plants and disease resistance (Sarkar et al., 2014).

Biofertilizers play a significant role in fixing atmospheric nitrogen, production of growth promoting substances and making phosphorous available to the plants hence the application of biofertilizers is very essential to the plant (Upadhayay et al., 1999).

\section{Materials and Methods}

A field experiment was conducted to study the effect of organic manures, organic supplements and biofertilizers on growth and yield of cowpea at Horticulture farm, Department of Horticulture, SHUATS during 2016-2017. The treatments consisted of $\mathrm{T}_{0^{-}}$ Control, $\mathrm{T}_{1^{-}}$Farm Yard Manure alone, $\mathrm{T}_{2^{-}}$ Farm Yard Manure + Fish Amino Acid, $\mathrm{T}_{3}-$ Farm Yard Manure + +Panchagavya, $\mathrm{T}_{4-}$ Farm Yard Manure + Fish Amino Acid + Panchagavya, $\mathrm{T}_{5^{-}}$Farm Yard Manure + Fish Amino Acid + Biofertilizer, $\mathrm{T}_{6}-$ Farm Yard Manure + Panchagavya + Biofertilizer, $\mathrm{T}_{7^{-}}$ Farm Yard Manure + Fish Amino Acid + Panchagavya +Biofertilizer, $\mathrm{T}_{8^{-}}$ Vermicompost alone, $\mathrm{T}_{9^{-}}$Vermicompost + Fish Amino Acid, $\mathrm{T}_{10^{-}}$Vermicompost + Panchagavya, $\mathrm{T}_{11^{-}}$Vermicompost + Fish Amino Acid + Panchagavya, $\mathrm{T}_{12^{-}}$ Vermicompost + Fish Amino acid + Biofertilizers, $\mathrm{T}_{13^{-}}$Vermicompost + Panchagavya + Biofertilizers, $\mathrm{T}_{14^{-}}$ Vermicompost + Fish Amino Acid + Panchagavya + Biofertilizers. The experiment was conducted following randomized block design replicated thrice. Sowing was done by keeping row to row distance of $60 \mathrm{~cm}$ and plant to plant of $30 \mathrm{~cm}$ on a plot measuring $1.7 \mathrm{~m} \times 2.1 \mathrm{~m}$. Different growth (days of $100 \%$ germination, plant height, number of branches, number of leaves, leaf area, number of nodules, days to first flower appearance), yield [pod yield per plant and pod yield ( $q / h a)$ ] parameters were studied during the field investigation.

\section{Results and Discussion}

The data presented in table 1 revealed that different treatments had significant influence on pre harvest growth attributes of cowpea such as days to $100 \%$ germination, plant height, number of branches, number of leaves, root nodules, days to flowering.

It is clear from table 1 that the earliest germination (3.3 days) was observed in $\mathrm{T}_{14}$ (Vermicompost + Fish Amino Acid + Panchagavya + Biofertilizer), $\quad \mathrm{T}_{12}$ 
(Vermicompost + Fish Amino Acid + Biofertilizers) (3.3 days) and $\mathrm{T}_{7}$ (FYM + Fish Amino Acid + Panchagavya + Biofertilizers) (3.3 days) followed by $\mathrm{T}_{13}$ (Vermicompost + Panchagavya + Biofertilizers) (3.7 days), $\mathrm{T}_{11}$ (Vermicompost + Fish Amino Acid + Panchagavya) (4.3 days), $\mathrm{T}_{6}$ ( $\mathrm{FYM}+$ Panchagavya + Biofertilizers) (3.7 days) and $\mathrm{T}_{4}$ ( FYM + Fish amino acid + Panchagavya) (4 days) which were found to be at par, whereas the lowest germination percentage was noticed in control (6.67 days). The number of days to germination is an important character which indicates earliness/ lateness of a crop in general. The presence of $\mathrm{N}$ indole-3-acetic acid (IAA), cytokinin, gibberellins, and humic acids in vermicompost could have been responsible for the faster germination of seeds (Aroncon et al., 2012).

At 60 days after sowing significant and highest plant height $(56.17 \mathrm{~cm})$ was observed in $\mathrm{T}_{14}$ (Vermicompost + Fish Amino Acid + Panchagavya + Biofertilizer) followed by $T_{13}$ (Vermicompost + Panchagavya + Biofertilizer) $(56.04 \mathrm{~cm}), \mathrm{T}_{12}$ (Vermicompost + Fish Amino Acid + Biofertilizer) (55.43 $\mathrm{cm}), \mathrm{T}_{11}$ (Vermicompost + Fish Amino Acid + Panchagavya) (52.77 cm), $\mathrm{T}_{7}$ (FYM + Fish Amino Acid + Panchagavya + Biofertilizer) $(55.80 \mathrm{~cm})$ and $\mathrm{T}_{6}(\mathrm{FYM}+$ Panchagavya+ Biofertilizer) $(54.00 \mathrm{~cm})$ which were on par. The least plant height $(46.23 \mathrm{~cm})$ was noted in control. Vermicompost improve the soil physical conditions and promote microbial and soil organic matter, which in turn produces organic acids, which inhibits enzymes, particularly IAA oxidase resulting in enhancing the promotive effect of auxinIAA which has direct effect on plant growth (Leopold, 1974). In case of Panchagavya and Fish Amino Acid, the easy transfer of nutrients to plant through foliar spray could have created the stimuli in the plant system which in turn increased the production of growth regulators in cell system resulting in higher plant height (Sarkar et al., 2014). Nitrogen and phosphorus play an important role in the synthesis of chlorophyll and amino acids. Rhizobium and PSB ensured the continuous supply of these nutrients during plant growth resulting in taller plants (Pawar and singh, 2003)

At 60 days after sowing $\mathrm{T}_{14}$ Vermicompost + Panchagavya + Biofertilizer showed significant and maximum number of branches per plant (28.93) followed by $T_{13}$ Vermicompost + Fish Amino Acid + Panchagavya + Biofertilizer (27.67) which were on par whereas minimum number of branches per plant (17.27) was observed in Control.

Similarly, at 60 days after sowing significant and maximum number of leaves per plant (57.07) was registered in $\mathrm{T}_{14}$ (Vermicompost + Fish Amino Acid + Panchagavya + Biofertilizer) followed by $\mathrm{T}_{13}$ (Vermicompost + Panchagavya + Biofertilizer) (56.93), $\mathrm{T}_{12}$ (Vermicompost + Fish Amino Acid + Biofertilizers) (53.33), $\mathrm{T}_{11}$ (Vermicompost + Fish Amino Acid + Panchagavya) (53.53), $\mathrm{T}_{10}$ (Vermicompost + Panchagavya) (50.47), $\mathrm{T}_{9}$ (Vermicompost + Fish Amino Acid) (56.33), $\mathrm{T}_{8}$ (Vermicompost alone) (51.20), $\mathrm{T}_{7}$ ( FYM + Fish Amino Acid + Panchagavya + Biofertilizers) (56.27), and $\mathrm{T}_{6}$ ( FYM + Panchagavya + Biofertilizers) (54.40) which were on par. The least number of leaves per plant (43.87) was noted in control. The number of branches and leaves due to application of organic manure may be attributed the fact that they possess optimum $\mathrm{C}$ : $\mathrm{N}$ ratio which on decomposition readily release nitrogen in the easily available form of nutrients ions such as ammonium and nitrate (Anuja and Vijayalakshma, 2014).

At the last harvest, significant and maximum number of nodules per plant (21.73) was 
recorded in $\mathrm{T}_{14}$ (Vermicompost + Fish Amino Acid + Panchagavya + Biofertilizer) followed by $\mathrm{T}_{13}$ (Vermicompost + Panchagavya+ Biofertilizer) (20.37), and $\mathrm{T}_{7}$ (Farm Yard Manure + Fish Amino Acid +Panchagavya + Biofertilizer) (19.93), whereas the least number of nodules per plant (9.93) was recorded in Control. Vermicompost not only supply the macro and micronutrients but also act as a store house of beneficial microorganisms hence enhanced the symbiotic relationship with micro- organism in the soil increasing in the number of nodules in the roots (Rajkhowa et al., 2003)

Significantly minimum number of days taken to first flower appearance was observed in $\mathrm{T}_{14}$ (Vermicompost + Fish Amino Acid +
Panchagavya + Biofertilizern) (27 days), $\mathrm{T}_{13}$ (Vermicompost + Panchagavya + Biofertilizer) (27 days) and $\mathrm{T}_{7}(\mathrm{FYM}+$ Fish Amino Acid + Panchagavya + Biofertilizer) (27 days), which were on par, whereas maximum number of days taken to first flower appearance (32 days) was observed in Control.

Days to first flower appearance take less number of days as this might be due to the combined application of the organic manures, organic supplements and biofertilizers and it has resulted more of vegetative growth and early flowering. The above findings are in confirmation with the research findings of Shrikant (2010) and Erdal et al., 2008.

Fig.1 Effect of organic manures, organic supplements and biofertilizers on pod yield per plant $(\mathrm{g})$ in cowpea

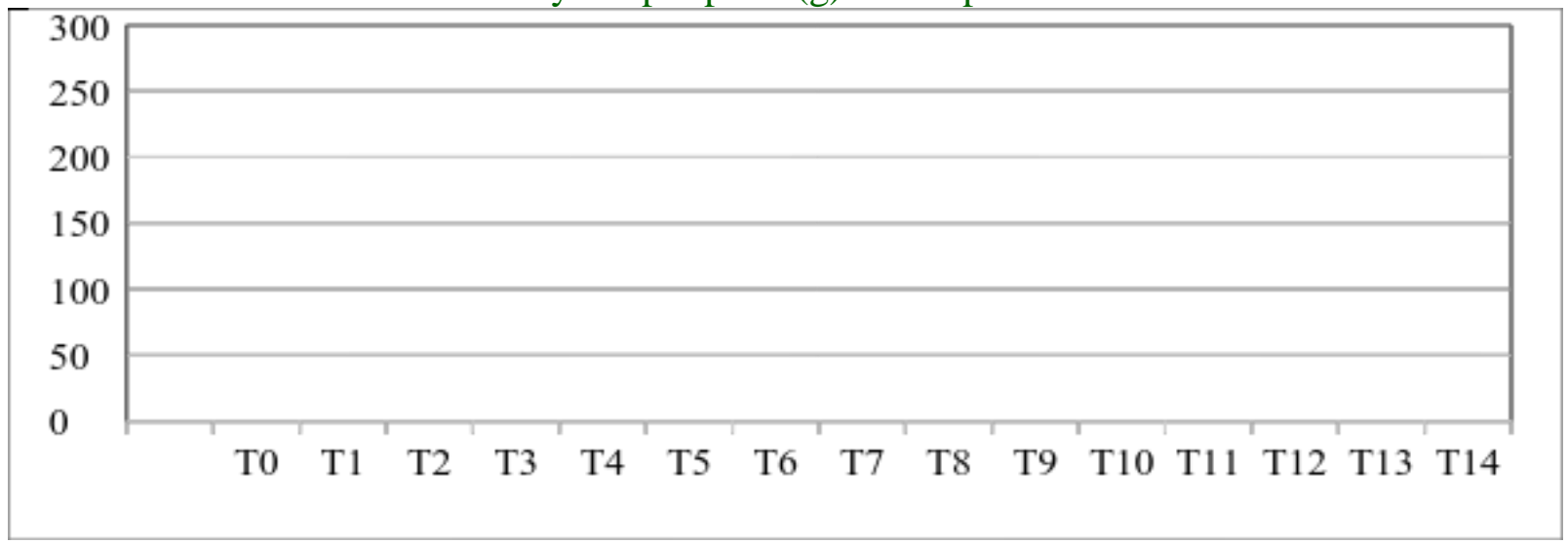

Fig.2 Effect of organic manures, organic supplements and biofertilizers on pod yield (q/ha) in cowpea

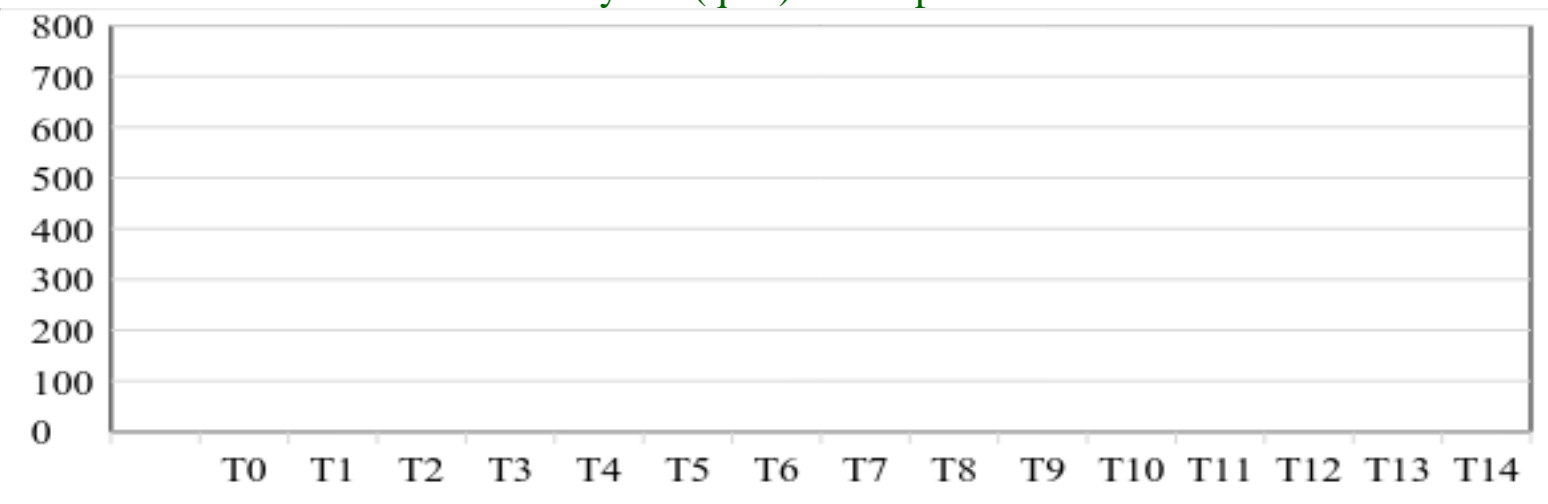


Table.1 Effect of organic manures, organic supplements and biofertilizers on pre-harvest observations of cowpea

\begin{tabular}{|c|c|c|c|c|c|c|}
\hline $\begin{array}{l}\text { Days to first } \\
\text { flower } \\
\text { appearance }\end{array}$ & $\begin{array}{l}\text { Root nodules } \\
\text { per plant } \\
\text { (At harvest) }\end{array}$ & $\begin{array}{l}\text { No. of leaves } \\
\text { per plant } \\
\text { (60 DAS) }\end{array}$ & $\begin{array}{l}\text { No. of } \\
\text { branches per } \\
\text { plant } \\
\text { (60 DAS) }\end{array}$ & $\begin{array}{l}\text { Plant height } \\
(\mathrm{cm}) \\
(60 \text { DAS })\end{array}$ & $\begin{array}{l}\text { Days to 100\% } \\
\text { germination } \\
\text { (60 DAS) }\end{array}$ & TREATMENTS \\
\hline 32 & 9.93 & 43.87 & 17.27 & 46.23 & 6.7 & $\mathrm{~T}_{0}$ \\
\hline 30 & 10.47 & 46.87 & 18.40 & 47.23 & 5.3 & $\mathrm{~T}_{1}$ \\
\hline 30 & 10.53 & 48.53 & 19.40 & 47.79 & 5.7 & $\mathrm{~T}_{2}$ \\
\hline 30 & 11.57 & 53.67 & 22.87 & 49.47 & 5.3 & $\mathrm{~T}_{3}$ \\
\hline 29 & 13.67 & 49.00 & 23.13 & 51.32 & 5.7 & $\mathrm{~T}_{4:}$ \\
\hline 28 & 16.40 & 49.33 & 23.39 & 52.03 & 4.0 & $\mathrm{~T}_{5}$ \\
\hline 28 & 17.74 & 54.40 & 25.30 & 54.00 & 3.7 & $\mathrm{~T}_{6:}$ \\
\hline 27 & 20.20 & 56.27 & 26.37 & 55.80 & 3.3 & $\mathrm{~T}_{7:}$ \\
\hline 29 & 10.67 & 51.20 & 19.87 & 48.53 & 5.3 & $\mathrm{~T}_{8}$ \\
\hline 30 & 12.20 & 56.33 & 23.27 & 50.50 & 4.7 & $\mathrm{~T}_{9}$ \\
\hline 30 & 14.67 & 50.47 & 23.40 & 51.70 & 5.0 & $\mathrm{~T}_{10}$ \\
\hline 30 & 17.53 & 53.53 & 24.42 & 52.77 & 4.3 & $\mathrm{~T}_{11}$ \\
\hline 28 & 19.93 & 53.33 & 25.81 & 55.43 & 3.3 & $\mathrm{~T}_{12}$ \\
\hline 27 & 20.37 & 56.93 & 27.67 & 56.04 & 3.7 & $\mathrm{~T}_{13}$ \\
\hline 27 & 21.73 & 57.07 & 28.93 & 56.17 & 3.3 & $\mathrm{~T}_{14}$ \\
\hline $\mathrm{S}$ & $\mathrm{S}$ & $\mathrm{S}$ & $\mathrm{S}$ & $\mathrm{S}$ & $\mathrm{S}$ & $\mathrm{F} \mathrm{Test}$ \\
\hline 0.38 & 1.35 & 3.76 & 0.73 & 1.96 & 0.73 & $\mathrm{SEd}=$ \\
\hline 0.77 & 2.77 & 7.70 & 1.49 & 4.02 & 1.49 & $\mathrm{CD}_{(\mathrm{P}=0.05 \%)}$ \\
\hline
\end{tabular}

Table.2 Influence of organic manures, organic supplements and biofertilizers on post- harvest observations of cowpea

\begin{tabular}{|c|l|l|l|c|c|c|c|}
\hline $\begin{array}{l}\text { Pod yield } \\
(\mathrm{q} / \mathrm{ha})\end{array}$ & $\begin{array}{l}\text { Pod yield } \\
\text { per plant } \\
(\mathrm{g})\end{array}$ & $\begin{array}{l}\text { No. of } \\
\text { seeds } \\
\text { per pod }\end{array}$ & $\begin{array}{l}\text { No. of } \\
\text { pods } \\
\text { per } \\
\text { plant }\end{array}$ & $\begin{array}{l}\text { Average } \\
\text { pod weight }\end{array}$ & $\begin{array}{l}\text { Width } \\
\text { of pods } \\
(\mathrm{cm})\end{array}$ & $\begin{array}{l}\text { Length of } \\
\text { pods (cm) }\end{array}$ & TREATMENTS \\
\hline 157.06 & 414.64 & 10.07 & 29.30 & 14.17 & 0.54 & 29.93 & $\mathrm{~T}_{0}$ \\
\hline 171.01 & 452.53 & 10.27 & 30.23 & 15.00 & 0.57 & 31.52 & $\mathrm{~T}_{1}$ \\
\hline 191.93 & 507.85 & 11.13 & 33.73 & 15.03 & 0.58 & 31.57 & $\mathrm{~T}_{2}$ \\
\hline 195.29 & 516.76 & 11.47 & 33.47 & 15.53 & 0.61 & 32.20 & $\mathrm{~T}_{3}$ \\
\hline 205.63 & 544.13 & 11.50 & 34.53 & 15.73 & 0.61 & 32.39 & $\mathrm{~T}_{4:}$ \\
\hline 226.05 & 598.17 & 13.07 & 36.13 & 15.57 & 0.62 & 34.10 & $\mathrm{~T}_{5}$ \\
\hline 234.71 & 620.96 & 13.53 & 36.67 & 16.90 & 0.63 & 35.20 & $\mathrm{~T}_{6:}$ \\
\hline 238.57 & 631.67 & 13.73 & 36.97 & 17.07 & 0.63 & 35.77 & $\mathrm{~T}_{7:}$ \\
\hline 193.61 & 512.23 & 12.03 & 33.07 & 15.47 & 0.59 & 31.87 & $\mathrm{~T}_{8}$ \\
\hline 207.81 & 549.97 & 12.47 & 34.40 & 15.70 & 0.61 & 32.30 & $\mathrm{~T}_{9}$ \\
\hline 207.06 & 548.04 & 13.13 & 35.40 & 16.53 & 0.62 & 33.40 & $\mathrm{~T}_{10}$ \\
\hline 226.13 & 598.27 & 13.13 & 36.17 & 16.63 & 0.62 & 34.15 & $\mathrm{~T}_{11}$ \\
\hline 237.98 & 629.70 & 13.77 & 36.93 & 16.97 & 0.63 & 35.47 & $\mathrm{~T}_{12}$ \\
\hline 240.00 & 635.07 & 13.93 & 37.17 & 17.10 & 0.66 & 36.19 & $\mathrm{~T}_{13}$ \\
\hline 254.03 & 671.97 & 14.10 & 37.70 & 17.63 & 0.69 & 36.84 & $\mathrm{~T}_{14}$ \\
\hline $\mathrm{S}$ & $\mathrm{S}$ & $\mathrm{S}$ & $\mathrm{S}$ & $\mathrm{S}$ & $\mathrm{S}$ & $\mathrm{S}$ & $\mathrm{F} \mathrm{Test}$ \\
\hline 20.89 & 55.33 & 0.94 & 1.50 & 1.54 & 0.04 & 1.86 & $\mathrm{SE} \mathrm{d}_{4}$ \\
\hline 42.80 & 113.34 & 1.93 & 3.06 & 3.15 & 0.09 & 3.82 & $\mathrm{CD}_{(\mathrm{P}=0.05 \%)}$ \\
\hline
\end{tabular}


The yield attributes of Cowpea viz., Pod length, pod width, average pod weight, number of pods per plant, number of seeds per pod were significantly influenced by the different treatments presented in table 2 .

Significant and maximum pod length (36.84 $\mathrm{cm}$ ) was observed in $\mathrm{T}_{14}$ (Vermicompost + Fish Amino Acid + Panchagavya + Biofertilizers) followed by $\mathrm{T}_{13}$ (Vermicompost + Panchagavya + Biofertilizers) $(36.19 \mathrm{~cm}), \mathrm{T}_{12}$ (Vermicompost + Fish Amino Acid + Biofertilizer) (35.47 $\mathrm{cm}), \mathrm{T}_{11}$ (Vermicompost + Fish Amino Acid + Panchagavya) (34.15 cm), $\mathrm{T}_{10}$ (Vermicompost + Panchagavya) $(33.40 \mathrm{~cm})$, $\mathrm{T}_{7}$ (FYM + Fish Amino Acid + Panchagavya+ Biofertilizer) $(35.77 \mathrm{~cm}), \mathrm{T}_{6}$ (FYM + Panchagavya + Biofertilizer) (35.20 $\mathrm{cm})$ and $\mathrm{T}_{5}(\mathrm{FYM}+$ Fish Amino Acid + Biofertilizers) $(34.10 \mathrm{~cm})$, whereas minimum pod length was observed in Control (26.93 $\mathrm{cm})$. Significantly maximum pod width $(0.69$ $\mathrm{cm}$ ) was observed in $\mathrm{T}_{14}$ (Vermicompost + Fish Amino Acid + Panchagavya + Biofertilizers) followed by $\mathrm{T}_{13}$ (Vermicompost + Panchagavya + Biofertilizers) $(0.66 \mathrm{~cm}) \mathrm{T}_{12}$ (Vermicompost + Fish Amino Acid + Biofertilizer) $(0.63 \mathrm{~cm})$, $\mathrm{T}_{11}$ (Vermicompost + Fish Amino Acid + Panchagavya) $(0.62 \mathrm{~cm}), \mathrm{T}_{10}$ ( Vermicompost + Panchagavya) $(0.62 \mathrm{~cm}), \mathrm{T}_{9}$ (Vermicompost + Fish Amino Acid) $(0.61 \mathrm{~cm}), \mathrm{T}_{7}(\mathrm{FYM}+$ Fish Amino Acid + Panchagavya+ Biofertilizer) $\quad(0.63 \mathrm{~cm}), \quad \mathrm{T}_{6} \quad(\mathrm{FYM}+$ Panchagavya+ Biofertilizer) $(0.63 \mathrm{~cm}), \mathrm{T}_{5}$ (FYM + Fish Amino Acid + Biofertilizers $)$ $(0.62 \mathrm{~cm})$ and $\mathrm{T}_{5}(\mathrm{FYM}+$ Fish Amino Acid + Biofertilizers $)(0.61 \mathrm{~cm}), \mathrm{T}_{4}(\mathrm{FYM}+$ Fish Amino Acid + Panchagavya) $(0.61 \mathrm{~cm})$ whereas minimum pod width was observed in Control $(0.54 \mathrm{~cm})$.

Significantly maximum average weight per pod $(17.63 \mathrm{~g})$ was observed in $\mathrm{T}_{14}$ (Vermicompost + Fish Amino Acid +
Panchagavya + Biofertilizers) followed by $\mathrm{T}_{13}$ Vermicompost + Panchagavya + Biofertilizers (17.10 g), $\mathrm{T}_{12}$ (Vermicompost + Fish Amino Acid + Biofertilizer) (16.97 g), $\mathrm{T}_{11}$ (Vermicompost + Fish Amino Acid + Panchagavya) (16.63 g), $\mathrm{T}_{10}$ ( Vermicompost + Panchagavya) (16.53 g) $\mathrm{T}_{9}$ (Vermicompost + Fish Amino Acid) (15.70 g), $\quad \mathrm{T}_{8}$ (Vermicompost alone) (15.47 g), $\mathrm{T}_{7}$ (FYM + Panchagavya+ Fish Amino Acid + Biofertilizer) (17.07 $\mathrm{g}), \quad \mathrm{T}_{6} \quad(\mathrm{FYM}+$ Panchagavya + Biofertilizers) (16.90 g), $\mathrm{T}_{5}$ (FYM + Fish Amino Acid + Biofertilizers $)$ $(16.57 \mathrm{~g}), \mathrm{T}_{4}(\mathrm{FYM}+$ Fish Amino Acid + Panchagavya) (15.73 g) $\mathrm{T}_{3} \quad(\mathrm{FYM}+$ Panchagavya) (15.53 g), $\mathrm{T}_{2}$ (FYM + Fish Amino Acid) (15.03 g), $T_{1}$ (FYM alone) $(15.00 \mathrm{~g})$, whereas minimum average weight per pod was observed in Control (14.17 g). Vermicompost treatments greater root extension under biofertilizers application might have helped in greater uptake of nutrients which ultimately improved the yield attributing characters like pod length, pod yield, pod weight, number of pods per plant and number of seeds per pod (Joshi et al., 2016).

From table 2, $\mathrm{T}_{14}$ (Vermicompost + Fish Amino Acid + Panchagavya + Biofertilizers) showed significant and maximum pod yield per plant $(671.97 \mathrm{~g})$ followed by $\mathrm{T}_{13}$ Vermicompost + Panchagavya + Biofertilizers (635.07 g), $\mathrm{T}_{12}$ (Vermicompost + Fish Amino Acid + Biofertilizer) (629.70 g), $\mathrm{T}_{11}$ (Vermicompost + Fish Amino Acid + Panchagavya) (598.27 g), T 7 (FYM + Fish Amino Acid + Panchagavya+ Biofertilizer) $(631.67 \mathrm{~g}), \mathrm{T}_{6}$ (FYM + Panchagavya+ Biofertilizer) (620.96 g) and $\mathrm{T}_{5}(\mathrm{FYM}+$ Fish Amino Acid + Biofertilizers) (598.17 g), whereas minimum pod yield per plant was observed in Control (414.64 g) (Fig. 1). Similarly treatment $\mathrm{T}_{14}$ (Vermicompost + Fish Amino Acid + Panchagavya + Biofertilizers) showed significantly maximum pod yield per 
quintal per hectare $(254.03 \mathrm{q} / \mathrm{ha})$ followed by $\mathrm{T}_{13}$ (Vermicompost + Panchagavya + Biofertilizers $) \quad(240.00 \quad \mathrm{q} / \mathrm{ha}) \quad \mathrm{T}_{12}$ (Vermicompost + Fish Amino Acid + Biofertilizer $) \quad(237.98 \quad \mathrm{q} / \mathrm{ha}), \quad \mathrm{T}_{11}$ (Vermicompost + Fish Amino Acid + Panchagavya) (226.13 q/ha), $\mathrm{T}_{7}$ (FYM + Fish Amino Acid + Panchagavya + Biofertilizer) (238.57 q/ha), $\mathrm{T}_{6}(\mathrm{FYM}+$ Panchagavya + Biofertilizer) $(234.71 \mathrm{q} / \mathrm{ha})$ and $\mathrm{T}_{5}(\mathrm{FYM}+$ Fish Amino Acid + Biofertilizers) (226.05 $\mathrm{q} / \mathrm{ha}$ ), whereas minimum pod yield quintal per hectare was observed in Control (157.06 q/ha) (Fig. 2). One of the factors responsible for pod yield in cowpea might be the different sources of organic manures, organic supplements and biofertilizers which are responsible for variations in the yield components like average pod weight, pod length, pod width, number of pods per plant, number of seeds per pod, pod yield per plant and pod yield per plot. These yield components had direct influence on the yield. Growth attributes viz., days to germination, plant height, number of branches, number of leaves, number of nodules and days to flower initiation have indirect effect on the yield of cowpea. Similar results were also reported by Takankar et al., (1998), Aruna and Narsa Reddy (1999).

In light of results obtained during the investigation, it is concluded that treatment $\left(\mathrm{T}_{14}\right)$ Vermicompost + Fish Amino Acid + Panchagavya + Biofertilizers emerged as superior over all other treatment and can be used to achieve quantitative, qualitative and sustainable production of cowpea.

\section{References}

Arancon, N.Q., Edwards, C.A., Atiyeh, R.M. and Metzger, T.D. (2004) Effect of vermicomposts produced from food waste on the growth and yields of greenhouse peppers. Bioresour.
Technol., 93: 139-144.

Aruna, P. and Reddy, N.S. (1999) Response of soybean (Glycine max) to conjunctive use of organic and inorganic sources of nitrogen. Indian J. Agric. Sci., 69(5): 382-383.

Anuja, S. and Vijayalakshmi, C.N (2014) Effect of organic nutrients on growth and yield of vegetable cowpea. The Asian Journal of Horticulture, 9 (1): 136-139

Baloch G.N., Tariq S., Ehteshamul-Haque S., Athar M., Sultana V. and Ara J. (2013) Management of root diseases of eggplant and watermelon with the application of asafoetida and seaweeds. Journal of Applied Botany and Food Quality 86: 138-142.

Davis, D.W., Oelke, E.A., Oplinger, E.S., Doll, J.D., Hanson, C.V. and Patnam, D.H. (2000) Alternative Field crops Manual. http.//www.Hort.purduc. edu/ newcrop/afcm/cowpea.html.

Erdal Elkoca. Faik Kantar and Fikrettin Sahin (2008) Influence of nitrogen fixing and phosphorous solubilizing bacteria on the nodulation, plant growth, and yield of Chickpea. J. Plant Nutrition, 31: 157171.

Gaur, A.C (1991) Bulky organic manures and crop residues.In: Fertilizers, organic matter recyclable wastes and biofertilizer H.L.S Tandon, Fertilizer development and consultation Organisation, New Delhi.

Giraddi, R.S., Radha, D., Kale and Biradar, D.P. (2001) Earthworms and organic matter recycling - an overview from Indian perspective. Karnataka J. Agric. Sci., 27 (3): (273-284).

Joshi et al., (2016) Effect of Organic manures on growth and yield of summer cowpea under middle Gujarat conditions. Agri. Sci. Digest., 36(2): 134-137.

Leopold, L.B. (1974) Reversal of Erosion Cycle and Climatic Change. Quatery 
Research 6, 557-562.

Pawar, A.S. and Singh, N.P. (2003) Effects of Conjunctive use of phosphorus and bioorganics on growth and yield of Groundnut (Arachis hypogaea). Indian J. of Agron., 48(3): 214-216.

Sarkar, S., Kundu, S.S. and Ghorai, D. (2014) Validation of ancient liquid organicsPanchagavya and Kunapajala as plant growth promoters. Indian Journal of Traditional Knowledge, 13(2): 398-403

Rajkhowa, D.J., Saikia, M. and Rajkhowa, K.M. (2003) Effect of vermicompost and levels of fertilizer on greengram. Legume Res., 26(1): 63-65

Takankhar, V.G., Mane, S. S., Kamble, B. G., and Surywanshi, A. P. (1998) Phosphorous uptake at different stages and yield attributes of grain crop as affected by $\mathrm{P}$ and $\mathrm{N}$ fertilization and Rhizobium inoculation. J. Soils and Crops, 8: 53-58.

Upadhayay, R.G., Sharma, S. and Drawal, N.S (1999) Effect of Rhizobium inoculation and graded level of Pea on the growth and yield of greengram. Legume Res., 22: 277-279.

Vasanthi, D. and Kurriaraswamy, K. (1999) Efficacy of vermicompost to improve soil fertility and rice yield. $J$. Indian Soc. Soil Sci., 47: 268-272.

\section{How to cite this article:}

Carol Lyngdoh, Vijay Bahadur, A.A. David, V.M. Prasad and Tajungsola Jamir. 2017. Effect of Organic Manures, Organic Supplements and Biofertilizers on Growth and Yield of Cowpea [Vigna unguiculata (L.) Walp]. Int.J.Curr.Microbiol.App.Sci. 6(8): 1029-1036. doi: https://doi.org/10.20546/ijcmas.2017.608.127 